\title{
Price Discrimination in Income Taxation
}

\author{
Benjamin Alarie*
}

January 16, 2012

\begin{abstract}
[Note to ALEA reviewers: Through a recent presentation of this paper to a partly American audience I have several US examples that I will be incorporating into this draft prior to the conference. These examples are not yet reflected in what follows, but will shortly be.]

Governments throughout the developed world claim to worry incessantly about the implications of sophisticated tax planning for their tax revenues. And yet the same governments routinely stop short of doing all that they can legally do to combat tax avoidance. Why? One response is that a thick conception of the rule of law constrains governments to adopt only certain kinds of responses to tax avoidance. Another response is that inherent structural limitations in tax administrative capacity or features of the political economy environment constrain the available responses to a subset of those that are possible de jure. Even considered jointly, however, the rule of law and the straightforward political economy explanations do not provide an
\end{abstract}

*B.A. (Wilfrid Laurier), M.A. (Toronto), J.D. (Toronto), LL.M. (Yale); Associate Dean, First Year Program and Associate Professor, Faculty of Law, Univeristy of Toronto. I am grateful to participants at presentations at the Annual Meeting of the Canadian Economics Association, the University of Toronto, ATAX at the Univeristy of New South Wales (Australia), McGill University, and the Deloitte / University of Waterloo Tax Policy Research Symposium. I am grateful also to Anita Anand, Ian Caines, Graeme Cooper, Tim Edgar, Victor Fleischer, Andrew Green, Richard Janda, Ed Iacobucci, Rod Macdonald, Alan Macnaughton, Matias Milet, Ryan Rabinovitch, Robert Raizenne, Emily Satterthwaite, Michael Smart, Charles Taylor, John Taylor, Michael Trebilcock, David Ulph, Michael Walpole, Brandon Wiener, Tom Wilson, Frances Wooley, and Albert Yoon for helpful conversations on earlier drafts. Please email comments and suggestions to ben.alarie@utoronto.ca. 
adequate account of the observed behavior of governments in the context of anti-avoidance. The main inadequacy is that the accounts do not provide an explanation of the circumstances that give rise to prolonged periods of inaction with respect to tax avoidance nor do they identify the circumstances that yield aggressive measures.

This paper introduces an "integrated price discrimination" account of anti-avoidance. An advantage of the integrated price discrimination account is that it better explains the observed practice of most developed countries with respect to anti-avoidance. Another advantage of the price discrimination account is that it does not require that governments adopt this approach consciously; it could simply be an unintentional byproduct of uncoordinated decisions taken by many government actors for disparate reasons. Several policy implications of the integrated price discrimination account are addressed.

\section{Introduction}

This paper offers a new way to approach an enduring puzzle. In the process it generates some counter-consensus implications for tax policy and administration, including the possibility that decisions to lower corporate tax rates do not constitute sound tax policy, ${ }^{1}$ that lukewarm or long-delayed efforts taken to combat tax avoidance may be understood in a new way, ${ }^{2}$ and that tax expenditures may be reconceptualized.

Let's begin with the puzzle. The puzzle is that while there are numerous legal tools available to governments seeking to counteract aggressive tax avoidance, many of the most effective anti-avoidance tools lie dormant and unused much of the time. Even such tools are used, they are deployed with a delay after new tax avoidance strategies come to light, and most of the time are effective only prospectively. This is true even though in many juris-

\footnotetext{
${ }^{1}$ For arguments that corporate income tax rates should be decreased see, for example, a recent opinion editorial by economist Martin Feldstein in the Wall Street Journal; Martin Feldstein, "Want to Boost the Economy? Lower Corporate Tax Rates" (February 15, 2011).

${ }^{2}$ This paper takes a different approach than others that have examined tax avoidance, regulatory arbitrage, and loopholes in the literature. Recent contributions that address related issues from different perpsectives include Leo Katz, "A Theory of Loopholes" (2010) 39(1) Journal of Legal Studies 1; Victor Fleischer, "Regulatory Arbitrage" (2010) 89 Texas Law Revew 227; and David Weisbach, "An Economic Analysis of Tax-Avoidance Doctrines" (2002) 4(1) American Law and Economics Review 88.
} 
dictions, including Canada (and arguably the United States, constitutional objections notwithstanding), the most effective legal tool of all is available to combat tax avoidance: retroactive specific anti-avoidance rules. ${ }^{3}$ It is thus puzzling why governments would consistently choose to countenance ongoing and significant forgone tax revenues. ${ }^{4}$ It is particularly puzzling at a time when government finances are in deficit throughout the developed world, and a mix of stimulus and austerity measures have been undertaken in economically significant jurisdictions. ${ }^{5}$ Many examples could be given of this governmental reluctance to use the full array of available anti-avoidance weapons. ${ }^{6}$ Given the legal powers governments have at their disposal, promi-

\footnotetext{
${ }^{3}$ Not all jurisdictions permit retroactive specific anti-avoidance rules, but Canada most certainly does. See, for example, the Supreme Court of Canada's judgment in Air Canada v. British Columbia, [1989] 1 S.C.R. 1161. Louis Kaplow states that, "[l]eading cases upholding retroactive tax legislation include Welch v. Henry, 395 U.S. 134 (1938); Brushaber v. Union Pac. R.R., 240 U.S. 1 (1916); and Stockdale v. Insurance Cos., 87 U.S. (20 Wall.) 323 (1873)." See Louis Kaplow, "An Economic Analysis of Legal Transitions" 99 Harv. L. Rev. 509 (1985-1986) at 565, fn. 162.

${ }^{4}$ It is particularly puzzling when governments complain about tax avoidance. See OECD, "The Global Forum on Transparency and Exchange of Information for Tax Purposes: A Background Information Brief" (March 16, 2011) available online at: http://www.oecd.org/dataoecd/32/45/43757434.pdf at p. 4.

${ }^{5}$ The United States has engaged in considerable quantitative easing since the outbreak of the financial crisis in 2008. The United Kingdom is probably the most prominent recent example of austerity measures, followed by less economically significant members of the EU, such as Greece. Most academic observers realize that it is only a matter of time that given the structural deficit in the United States it will have to follow by introducing austerity measures. At least for now Canada is on relatively stronger fiscal footing at the federal level; some provincial finances are in poorer shape, such as in Ontario and Québec. On the poor shape of the finances of the Province of Québec, see Pierre Fortin, "Staying the Course: Québec's Fiscal Balance Challenge" (March 2011) C.D. Howe Institute Commentary No. 325, available online at: http://www.cdhowe.org/pdf/Commentary_325_en.pdf.

${ }^{6}$ Any time there is transitional relief such as, for example, grandfathering, government reluctance to combat tax avoidance is at work. Transitional relief is common and has been subjected to withering criticism in the legal literature from an economic perspective. See, for example, Michael Graetz, "Legal Transitions: The Case of Retroactivity in Income Tax Revision" (1977) 126 University of Pennsylvania Law Review 47; Michael Graetz, "Retroactivity Revisited" (1985) 98(8) Harvard Law Review 1820; Louis Kaplow, "An Economic Analysis of Legal Transitions" (1986) 99 Harvard Law Review 509; and Daniel Shaviro, When Rules Change: The Economics of Retroactivity (University of Chicago Press, 2000).
} 
nent Canadian tax scholars, including Brian Arnold, ${ }^{7}$ Neil and Kim Brooks, ${ }^{8}$ David Duff, ${ }^{9}$ Tim Edgar, ${ }^{10}$ and Jinyan Li and Daniel Sandler, ${ }^{11}$ appear to oscillate between urging a more active approach to combating tax avoidance on the one hand, and despairing of ever gaining traction in the fight against tax avoidance on the other. Tax planners in private practice, including both lawyers and accountants, are often left with a vague sense of uneasiness for related reasons. For tax planners the source of uneasiness lies in questions such as, "For how long will my clients be able to engage in these sophisticated tax mitigation strategies that are (at least seemingly) inconsistent with prudent fiscal policy?"12 and "How confident should I be in advising

\footnotetext{
${ }^{7}$ Brian Arnold has long been an advocate of a strong and effective general anti-avoidance rule ("GAAR"). He has written that, "The GAAR can be seen as a necessary and measured response by Parliament, after trying all other possible responses, to the serious problem of abusive tax avoidance. Such tax avoidance undermines the fairness and integrity of the tax system. It is not inconceivable that the courts might view their role as assisting Parliament - or at least not frustrating the will of Parliament - in carrying out its clear intention to prevent abusive tax avoidance." See Brian J. Arnold, "The Long, Slow, Steady Demise of the General Anti-Avoidance Rule" (2004) 52(2) Canadian Tax Journal 488 at 491.

${ }^{8}$ In a recent essay paying tribute to the recently-retired Chief Justice Bowman of the Tax Court of Canada, Neil and Kim Brooks write in the Canadian Tax Journal that, "Although this is not the place to rehearse the arguments, to fully reveal our theoretical hand, we believe that judges should always consider consequences in reaching their decisions, should always characterize transactions with regard to their economic substance, and should be quick to set aside tax-avoidance transactions." See Neil Brooks and Kim Brooks, "Going for the Jugular: Justice Bowman's Approach to the Craft of Judging" (2010), 58 (Special Supplement) Canadian Tax Journal 5 at 8.

${ }^{9}$ David Duff argues in favour of a pragmatic approach to interpreting the Income Tax Act and, it is fair to say, regards the courts as playing an important safeguarding role in the fight against tax avoidance. See David G. Duff, "Justice Iacobucci and the 'Straight and Golden Metwand' of Canadian Income Tax Law" (2007) 57 University of Toronto Law Journal 525 at 570 .

${ }^{10}$ Tim Edgar has argued that "tax avoidance should be regarded as a negative externality, and externality theory suggests appropriate policy instruments that can be used to eliminate the consequential attributes of avoidance behavior"; see Tim Edgar, "Building a Better GAAR" (2007) 27 Virginia Tax Review 833 at 833.

${ }^{11}$ See Jinyan Li and Daniel Sandler, "The Relationship Between Domestic AntiAvoidance Legislation and Tax Treaties" (1997) 45(5) Canadian Tax Journal 891.

${ }^{12} \mathrm{An}$ example of a manifestation of this kind of concern erupting in Canada is associated with the 2007 introduction of section 18.2 of the Income Tax Act. Section 18.2 would have precluded the deduction of "double-dip" interest and would have taken effect beginning in 2011. However, in response to a storm of protest and a strong adverse reaction by both big businesses and the tax planning community, section 18.2 was repealed in 2009. As
} 
my clients that our proposed tax mitigation strategy will be successful?"13 From either the academic or from the private practice perspective, the approaches taken by governments in combating tax avoidance are slow in coming and are often half-hearted when they do emerge. What accounts for the puzzling phenomenon of government restraint, temporally and in tactics, in anti-avoidance?

There are two conventional accounts that might be given as to why governments are soft on tax avoidance. The first account invokes the rule of law to make the case that many of the most effective anti-avoidance strategies, such as retroactive legislation, are inherently antithetical to the principles and aspirations of modern legal systems and, for that reason, off the table (except perhaps in the most exigent circumstances). ${ }^{14}$

The second account takes seriously the political economy hurdles militating against vigilance in enforcing tax laws. It may, for example, be extremely difficult to tackle aggressive tax avoidance because of the political clout of the economic interests favoured by inaction ${ }^{15}$ and the practical difficultly of

such, section 18.2 never had an opportunity to take effect.

${ }^{13}$ Consider, for example, the intense attention paid by the tax planning community to developments surrounding the general anti-avoidance rule. See Harry Erlichman, ed., Tax Avoidance in Canada: The General Anti-Avoidance Rule (Irwin Law, 2002); and David G. Duff and Harry Erlichman, eds., Tax Avoidance in Canada After Canada Trustco and Mathew (Irwin Law, 2007).

${ }^{14} \mathrm{On}$ the influence of the concept of the rule of law in matters of taxation see Geoffrey Loomer, "Taxing out of Time: Parliamentary Supremacy and Retroactive Tax Legislation" [2006] British Tax Review 64; and Thomas E. McDonnell, "Retroactivity: Policy and Practice," in report of Proceedings of the Fifty-Eighth Tax Conference, 2006 Conference Report (Toronto: Canadian Tax Foundation, 2007), 2:1-33.

${ }^{15} \mathrm{~A}$ recent opinion editorial in the Wall Street Journal gives a sense of the rancor involved in suggesting that tax laws should be more effectively enforced.

The White House is requesting that the most beloved of all government agencies get an additional 5,100 agents next year, no doubt to wring further tax revenue from Americans. The White House wants to give the IRS a 9.4\% raise in fiscal 2012 , to $\$ 13.28$ billion. Reuters reports this would allow for a roughly $5 \%$ increase in agency manpower to 100,537 , including $\$ 460$ million more for tax enforcement than in 2010 .

We doubt this is the kind of fiscal discipline that voters had in mind in November, but it does reflect the mentality of an Administration that assumes it could go a long way to balancing the budget if only fewer Americans shirked their tax bills. The 5,100 extra IRS gumshoes are supposed to chase the $\$ 300$ billion 'tax gap,' the Beltway's version of the Loch Ness monster that is the difference between what the IRS collects and what Congress 
mobilizing tax authorities to revisit earlier tax assessments. On the political economy view then, governments may often choose to acquiesce in significant tax avoidance in order to appease various influential interests and also because tax administrators face asymmetries in resources, information, and incentives vis-à-vis economically sophisticated taxpayers.

Within certain domains each of the two conventional accounts has considerable purchase. However, the two accounts fall short of offering a satisfactory narrative of the observed dynamic in tax avoidance. More specifically, the rule of law and political economy do not provide an adequate explanatory account of when and why governments step in to curb tax avoidance. The rule of law account explains why government will tend to take anti-avoidance measures that operate only prospectively (to satisfy the central major constraint under the rule of law account). The political economy account does have an account of why governments do eventually engage in anti-avoidance (to ensure adequate revenues for the operation of government). Neither account explains why, however, the dominant approach is not to lower tax rates and then vigilantly enforce them. ${ }^{16}$ Moreover, neither account entirely squares with observed government practice in the context of anti-avoidance. For example, governments are more likely to step up to certain kinds of tax avoidance than others (for example, that engaged in by employees), and are more likely to make certain kinds of tax changes retroactively effective. ${ }^{17}$ The challenge then is to explain why there are lags in the response to anti-avoidance, and why anti-avoidance measures are sometimes made retroactively effective rather than only prospectively effective. ${ }^{18}$ Is there, in other words, a superior

thinks Americans owe. It's about as real as Nessie, though at least with the monster some Scots claim photographic evidence.

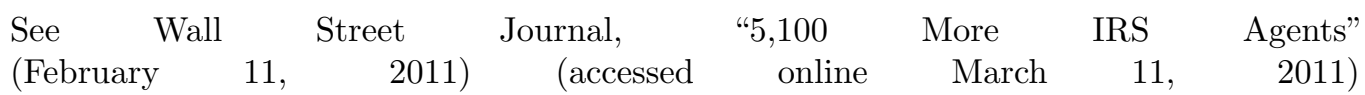
http://online.wsj.com/article/SB10001424052748703703804576144774072723648.html

${ }^{16}$ There are now movements afoot, most prominently in Canada and the UK, to lower corporate income tax rates. Canada's current target combined federal-provincial corporate tax rate is $25 \%$ (in Ontario) by 2012 and the UK's target corporate tax rate is $24 \%$ by 2014; see Geoffrey Loomer, "International Tax Avoidance After the 2008 Financial Crisis: Canada's Complicity" (draft paper dated March 15, 2011 on file with author) at 10.

${ }^{17}$ In Canada, at least, governments appear to be most willing to introduce retroactive taxes in situations where the alternative exposes them to having to disgorge unconstitutionally collected taxes. See Benjamin Alarie, "Kingstreet Investments: Taking a Pass on the Defence of Passing On" (2008) 46(1) Canadian Business Law Journal 36.

${ }^{18}$ There is an excellent literature in law and economics that analyzes the effects of 
account available of what is giving rise to the observed practice?

This paper provides an outline of a superior account. More specifically, this paper makes two contributions. The first contribution is that while the "wait-and-see" approach often taken by governments is associated with inefficiently high real resources dedicated to tax planning (because real resources are expended to avoid a transfer), it may also have salutary affects through what economists would recognize as a method of price discrimination. The second contribution is to point out that to maintain this price discrimination it is perhaps inevitable that there will be an ongoing dynamic in which governments address tax avoidance principally when it threatens to ripen into widespread tax avoidance among less responsive taxpayers. ${ }^{19}$ Considered jointly, these two observations provide a new way of understanding and resolving the puzzle of half-hearted anti-avoidance. This new understanding also helps to determine the contexts in which the response to tax avoidance is likely to be slow in coming from the contexts in which the response will be more aggressive.

To the end of describing this previously undeveloped aspect of the explanation for lax anti-avoidance this paper proceeds as follows. Part 2 sets up the puzzle of lax anti-avoidance by outlining the array of anti-avoidance instruments that governments may avail themselves of in combating tax avoidance, including retroactive specific anti-avoidance rules, general antiavoidance rules coupled with penalties, and multiple alternative tax bases. Part 3 elaborates on the rule of law and political economy explanations that provide a partial basis for half-hearted anti-avoidance. Part 4 describes the central contribution of this paper: the mechanism by which governments engage (perhaps unintentionally) in second-degree price discrimination through the income tax system. Part 5 explores the implications of this insight for tax policy and administration. Part 6 concludes.

\section{The Puzzle}

The puzzle that this paper addresses is the observation that governments do not consistently act more decisively to combat tax avoidance given the potency of the legal tools at their disposal. There are numerous particular instances of the puzzle that might be given in numerous countries. In the

retroactivity and transititional relief; see supra note 6 .

${ }^{19}$ The differing "responsiveness" of taxpayers is addressed below in 4.2.2. 
Canadian context, examples include (1) the reluctance to embrace limitationon-benefits (LOB) clauses in our tax treaties and the reliance instead on ineffective measures such as "beneficial ownership" or the general anti-avoidance rule; and (2) the long-standing ability for foreign affiliates with taxable surplus to make interest-free "upstream loans" to Canadian companies. ${ }^{20}$ Some of the instances consistent with the observed puzzle are related to particular tax avoidance schemes and the delay associated with introducing legislation to address the associated tax avoidance. ${ }^{21}$ Other instances constitute the presence of anti-avoidance tools that are mostly unused despite their obvious utility and effectiveness in combating tax avoidance. Among these are retroactive specific anti-avoidance rules, general anti-avoidance rules with penalties, and the use of multiple alternative tax bases.

Governments themselves recognize that they have many more tools to combat tax avoidance than they are willing to use. After circulating a working paper entitled, "Aggressive Tax Planning" in January 2009 and seeking input on appropriate measures to combat tax avoidance, ${ }^{22}$ the Province of Québec embraced several measures to combat aggressive tax planning. Among the measures ultimately adopted were: (1) mandatory disclosure of certain tax plans; (2) a general anti-avoidance rule enforced with a penalty;

\footnotetext{
${ }^{20}$ It appears that the second of these is going to be addressed, however, with the proposed subsections 90(4) to (10) of the Income Tax Act.

${ }^{21}$ For a recent instance along these lines, consider the Canadian experience with the taxation of income trusts. Although the first income trusts were adopted in the mid-1990s, the income trust did not swell in popularity until after 2000. By September 2005 it was clear that the federal government was concerned about the tax deferral associated with income trusts when the Department of Finance issued a white paper on the taxation of income trusts and suspended issuance of advance tax rulings to businesses seeking to convert to the income trust form. See Department of Finance, "Tax and Other Issues Related to Publicly Listed Flow-Through Entities (Income Trusts and Limited Partnerships)" (September 8, 2005) available at: http://www.fin.gc.ca/activty/pubs/flwthruent_e.pdf . In a surprise announcement on November 23, 2005, the federal government announced that it would seek to address the income trust issue by providing for improved integration between corporate and individual level taxes. This reform proved to be inadequate to stem the tide of conversions to the income trust format, and so the federal government announced on October 31, 2006, a new tax on "specified investment flow-through" entities that would essentially income trusts the same was as publicly-traded corporations. While this raised the ire of the income trust lobby, it was successful in eliminating the tax advantages associated with income trusts. The income trust index fell by more than $16 \%$ on November 1, 2006, reflecting the loss of the tax advantages associated with income trusts.

${ }^{22}$ See Revenu Québec, Aggressive Tax Planning: Working Paper (January 2009) available online at: http://www.finances.gouv.qc.ca/documents/Autres/en/AUTEN_DocCons_PFA.pdf.
} 
and (3) voluntary preventative disclosure. ${ }^{23}$ The most notable feature of the collection of measures adopted is that the province refused to categorically and unequivocally endorse the use of retroactive specific anti-avoidance rules. $^{24}$

\subsection{Retroactive Tax Legislation}

Retroactive tax legislation is legally available in many major tax jurisdictions, and is often regarded as being essential to the operation of mature tax systems. For example, when new budgets are announced and fiscal changes are proposed, it is understood that if the budget measures are passed, they will be passed with an effective date that matches the date the proposals were initially made. This is essential to prevent "policy runs" (along the lines of "bank runs") in which a strong behavioral response in anticipation of future events occurs.

In Canada that there are no constraints on the imposition of retroactive tax legislation so long as Parliament's intent in making a particular law retroactive in effect is clear. This has been reiterated by the Supreme Court of Canada on several occasions, including quite recently. ${ }^{25}$ Parliament typically satisfies the burden of clearly indicating its intention for law to be effective retroactively by stipulating the date from which an amendment is to take effect. For example, in May 2005 the general anti-avoidance rule of section 245 of the Income Tax Act was amended retroactively to its original effective date of September 1988. ${ }^{26}$ The amendment was necessary ostensibly because of the decision of the Federal Court of Appeal in MIL (Investments) S.A. v. $\mathrm{R} .{ }^{27}$ in which a unanimous panel held that the general anti-avoidance rule did

\footnotetext{
${ }^{23}$ See Revenu Québec, "Information Bulletin 2009-5: Fighting Aggressive Tax Planning" (October 15, 2009) available online at: http://www.finances.gouv.qc.ca/documents/bulletins/en/BULEN_2009-5-a-b.pdf

${ }^{24}$ In the working paper of January 2009, supra note 21, Revenu Québec stated at 51 that, "Although some arguments against retroactive legislative amendments may have some merit, nonetheless, in some circumstances, such amendments are the best solution." Despite this, however, the measures announced in October 2009 did not adopt retroactive responses to tax avoidance as a central means of anti-avoidance.

${ }^{25}$ On the constitutionality of retroactive tax legislation, see Benjamin Alarie, "Retroactivity and the General Anti-Avoidance Rule" in D. Duff and H. Erlichman, eds., Tax Avoidance in Canada after Canada Trustco and Mathew (Irwin Law, 2007) at 197-219.

${ }^{26}$ See ibid.

${ }^{27} 2007$ FCA 236, affirming 2006 D.T.C. 3307 (Eng.), [2006] 5 C.T.C. 2552, 2006 Car-
} 
not apply to the abuse of income tax treaties in the treaty shopping context. A more general concern was also addressed that, in light of the ruling in MIL (Investments) S.A., perhaps the abuse of other statutes would be taken as shielding taxpayers from the application of the general anti-avoidance rule.

Joining retroactivity with specific anti-avoidance rules is the most potent weapon available to governments in combating tax avoidance. ${ }^{28}$ Specific antiavoidance rules are, as the name suggests, rules that are introduced in order to render unattainable certain tax advantages that might otherwise be available to taxpayers. Take just one example as representative. The tax unit in Canada is the individual. The ability of spouses to transfer property to one another means that a simple way to transfer income from one spouse to the other would be for a high income earning spouse to transfer investments to a lower income earning spouse so that the investment returns accrue to the spouse with lower income. Because of the progressive marginal rate structure this strategy would, without a specific anti-avoidance rule, result in tax reducing income splitting. To combat this possibility and to help ensure the integrity of the individual tax unit, there are spousal attribution rules in the Income Tax Act that attribute income earned on investments back to the spouse who transferred the property originally. ${ }^{29}$ More generally, specific anti-avoidance rules are used to block certain avenues of tax avoidance and to channel taxpayer behavior into desired (tax-liability-incurring and revenuecollecting) pathways.

\subsection{General Anti-Avoidance Rules with Penalties}

Many OECD countries have incorporated general anti-avoidance rules into their income tax systems. These are rules that typically stipulate that some tax avoidance schemes will not deliver the tax benefit claimed by taxpayers, and hence be ineffective, under certain stipulated conditions. A number of authors have called into question the effectiveness of general anti-avoidance rules insofar as they serve to vary the tax consequences dictated by the application of detailed tax rules through the use of a difficult to define standard

swellNat 2558, 2006 TCC 460 (T.C.C.).

${ }^{28}$ See the discussion in Revenu Québec, supra note 23.

${ }^{29}$ See, for example, sections 73 and 74.1, 74.2, and 74.5 of the Income Tax Act, R.S.C. 1985 , c. 1 (5th Supp.), as amended. 
against impermissible tax avoidance. ${ }^{30}$

While the substance of these objections is weighty, they should not end discussion on the matter. Indeed, in earlier work I have contended that one of the central purposes of general anti-avoidance rules is to put taxpayers on notice that they should not reasonably expect to retain the tax benefits claimed from aggressive tax planning. ${ }^{31}$ From this perspective the main point of a general anti-avoidance rule is not to itself counter overly aggressive tax avoidance but to instead put taxpayers on notice in a formal way that the benefits that they may claim based on literal adherence to the text of tax legislation and from respect for the formal legal substance of transactions may be elusive. Thus, a general anti-avoidance rule may serve primarily as paving the way for retroactive specific anti-avoidance rules that address an "abus de droit" that might otherwise go unaddressed.

Canada's general anti-avoidance rule does not provide for any penalties if and when it applies. This is itself a puzzle. If the goal is to encourage taxpayers not to adopt aggressive tax avoidance strategies, it is difficult to see how a rule that merely has the prospect of denying the tax benefits of a plan should do anything to curb the practice. Conceptually there is no reason for taxpayers not to gamble with whether a particular tax avoidance strategy will be challenged by the tax authorities, since there is everything to gain if the taxpayer is lucky, and nothing to lose (except the tax benefit) if the taxpayer is unlucky.

One explanation for why Canada's general anti-avoidance rule does not have a penalty is that Parliament is concerned that the determination by the courts as to whether a particular avoidance transaction gives rise to a tax benefit that should be reversed by the general anti-avoidance rule would be affected by the existence of a penalty. The thinking here is that the courts are apt to anticipate the consequences of determining whether the preconditions for the application of the general anti-avoidance are satisfied before finding that they are indeed satisfied. ${ }^{32}$

\footnotetext{
${ }^{30}$ See, for example, Benjamin Alarie, "Trebilcock on Tax Avoidance" (2010) 60(2) University of Toronto Law Journal 623.

${ }^{31}$ Ibid., at 632 .

${ }^{32}$ The courts in Canada have expressed considerable reluctance to apply the general anti-avoidance rule even though its application does not result in a taxpayer penalty but merely serves to deny a tax benefit. This can largely be attributed to the legacy of the Duke of Westminster. On the lasting influence of UK tax concepts on Canadian income tax law, see Benjamin Alarie and David G. Duff, "The Legacy of UK Tax Concepts in
} 


\subsection{Multiple Alternative Minimum Taxes}

Many income tax systems in OECD countries, including Canada ${ }^{33}$ and the United States, ${ }^{34}$ use various kinds of AMTs ("alternative minimum taxes") as backstops to their ordinary tax systems in order to ensure that taxpayers that are able to take advantage of undue amounts of tax relief according to the ordinary tax base rules are still liable to pay a baseline amount of income tax. The use of AMTs is controversial. ${ }^{35}$ AMTs take different forms and vary in their prevalence according to the jurisdiction, but the general idea is the same.

It is not at all obvious logically that the use of alternate tax bases should stop at one. There could be as many alternate tax bases deployed in any country's income tax system as there are reasonable proxies for ability to pay income tax. ${ }^{36}$ Among the most obvious contenders would be proxies for ability to pay, such as net assets, revenues, cash flow, and financial accounting profits. While each of these alternative bases has problems in that they each more or less only crudely track the criterion of interest (ability to pay), if the rule for basing tax liability upon them was determined with sufficient care, these shortcomings might well be largely eliminated.

Indeed, once alternative bases are specified, it would be relatively straightforward to stipulate a base choosing rule to determine which of the alternative

Canadian Income Tax Law" [2008] British Tax Review 228.

${ }^{33}$ On the Canadian alternative minimum tax, see Gilles N. Larin and Marie N. Jacques, "Is the Alternative Minimum Tax a Paper Tiger?" (1994) 42(3) Canadian Tax Journal 804.

${ }^{34}$ On the US alternative minimum tax, see Leonard E. Burman, William G. Gale, and Jeffrey Rohaly, "The Expanding Reach of the Individual Alternative Minimum Tax" (2003) 17(2) Journal of Economic Perspectives 173; Andrew B. Lyon, Cracking the Code: Making Sense of the Corporate Alternative Minimum Tax (Brookings Institution Press, 1997); and Andrew B. Lyon and Gerald Silverstein, "The Alternative Minimum Tax and the Behavior of Multinational Corporations" in Martin B. Feldstein, James R. Hines, Jr., and R. Glenn Hubbard, eds., The Effects of Taxation on Multinational Corporations (University of Chicago Press, 1995), 153-180.

${ }^{35}$ See, for example, Andrew B. Lyon, "Why a Minimum Tax?" in Report of Proceedings of the Forty-Third Tax Conference, 1991 Conference Report (Toronto: Canadian Tax Foundation, 1992), 18:1-10. Lyon asserts at 18:10 that, "Why a minimum tax? It can accomplish nothing that cannot be accomplished by the regular tax system. At best, a CMT is, as Senator Bradley remarked, an admission of failure. At worst, it compounds the flaws of an existing tax system."

${ }^{36}$ An example of such taxes are capital tax regimes. Canada's federal capital tax regime for corporations was repealed effective July 1, 2010. 
taxes is to govern the tax liability of a given taxpayer for any given time period. Suppose that, as suggested above, there were five alternative tax bases specified. You could sort the provisional tax liabilities generated by each of these alternate taxes according to their size from largest to smallest for any given taxpayer in any given year. Unlike current income tax systems, which contemplate a default tax system and a single alternative minimum tax, there is in principle no reason to designate any particular alternative tax base as being "the" default. Instead, the default might variously be the tax liability calculated under the median tax system of the five, the average of the middle three, the average of all five, the second smallest, the second largest, etc. There are, in short, many possibilities. There is important work to be done in analyzing the possibilities for multiple alternative minimum taxes to serve as a more reliable and robust guide to taxation.

The advantage of expanding the basic idea of the AMT to embrace additional alternate taxes is that the returns to tax planning can be sharply reduced, depending on the design of the system according to the alternate taxes used and the decision rule surrounding which of the alternate taxes should be used to decide final tax liability. The reason is that the sensitivity of final tax liability to any given tax plan that economizes on one or more of the alternate taxes is apt to be rather low. It would be difficult to simultaneously devise a tax avoidance strategy that simultaneously avoids all five alternate taxes simultaneously in a way that does not also reduce a taxpayer's ability to pay.

\section{Conventional Accounts}

There are at least two conventional accounts of why governments do not do more to counter tax avoidance. The first account highlights the rule of law as a disciplining mechanism on the more aggressive responses to tax avoidance that might be necessary to stem it in a tax system with relatively high marginal tax rates. The second account highlights the political environment that might render an otherwise effective response to tax avoidance ill-advised. While each of the accounts is seriously incomplete on its own terms, they are each an important element of an understanding of the observed behavior of governments in the context of tax avoidance. The picture will only be completed in Part 4 with the price discrimination account. 


\subsection{The Rule of Law}

Friedrich August Hayek articulated the concept of the rule of law as follows, "stripped of all technicalities this means that government in all its actions is bound by rules fixed and announced beforehand - rules which make it possible to foresee with fair certainty how the authority will use its coercive powers in given circumstances, and to plan one's individual affairs on the basis of this knowledge." 37 Closer to home, the rule of law has been described by the Supreme Court of Canada as, "a highly textured expression ... conveying, for example, a sense of orderliness, of subjection to known legal rules and of executive accountability to legal authority." ${ }^{38}$ Contemporary authors, included among them Tom Bingham and Brian Tamanaha, have pointed out that the idea of the rule of law can be authoritatively traced to the writings of the Ancients. ${ }^{39}$ More recently, however, credit for popularizing the concept of the rule of law is often given to British jurist Albert Venn Dicey. ${ }^{40}$

What precisely did Dicey mean by the expression the "rule of law"? Dicey described three distinct meanings for the phrase "the rule of law." Only the first of is these meanings is directly apposite to taxation. The primary meaning Dicey gave to the rule of law is that, "no man is punishable or can be made to suffer in body or goods except for a distinct breach of law established in the ordinary legal manner before the ordinary courts of the land." ${ }^{41}$ Rawls

\footnotetext{
${ }^{37}$ See Friedrich August Hayek and Bruce Caldwell, The Road to Serfdom: Text and Documents, The Definitive Edition (University of Chicago Press, 2007) at 112.

${ }^{38}$ Reference re a Resolution to amend the Constitution, [1981] 1 S.C.R. 753, at 805-806.

${ }^{39}$ See Tom Bingham, The Rule of Law (Penguin, 2010) at 3. Bingham reports that a literal translation of Aristotle produces, "It is better for the law to rule than one of the citizens" and "so even the guardians of the laws are obeying the laws." See also Brian Tamanaha, On the Rule of Law (Cambridge University Press, 2004) at 7-14. Additional sources on the rule of law include Richard H. Fallon Jr., "The Rule of Law as a Concept in Constitutional Discourse" (1997) 97 Columbia Law Review 1; Judith N. Shklar, "Political Theory and the Rule of Law" in Hutchinson and Monahan, eds., The Rule of Law: Ideal or Ideology (Toronto: Carswell, 1987); and Jeremy Waldron "Is the Rule of Law an Essentially Contested Concept?" (2002) 21(2) Law \& Philosophy 137.

${ }^{40}$ The principal work is A.V. Dicey, An Introduction to the Law of the Constitution (1885). For a discussion of Dicey's contributions to the popularization of the idea of the rule of law, see Richard A. Cosgrove, The Rule of Law: Albert Venn Dicey, Victorian Jurist (London: Macmillan, 1980).

${ }^{41}$ See Dicey, ibid. The second meaning for Dicey was that, "No man is above the law, but ... whatever his rank or condition is, he is subject to the ordinary law of the realm and amenable to the jurisdiction of the ordinary tribunals." The third meaning of the rule of law was, "We may say that the constitution is pervaded by the rule of law on the ground
} 
built on Dicey's account, and subsequently identified five requirements of the rule of law: (1) compliance must be possible; (2) there must be regularity; (3) there must be publicity; (4) there should be generality to law; and (5) there must be respect for due process. ${ }^{42}$ Joseph Raz has also articulated an influential set of requirements of the rule of law. ${ }^{43}$ Others, including Lon Fuller, have also attempted similar lists. ${ }^{44}$

While there has been some writing in the academic tax literature on the rule of law, it is relatively limited. Geoffrey Loomer argued in a 2006 article in the British Tax Review that unwritten constitutional principles relating to the rule of law might well legitimately constrain the domain for Parliament to respond with retroactively effect tax legislation. ${ }^{45}$ In another recent publication, Thomas E. McDonnell argues that in the taxation context the rule of law can be regarded as entailing four specific consequences with respect to retroactive legislation: "(1) that curative amendments are always acceptable; (2) that a taxpayer who has reasonably relied on the state of the existing law has an interest worthy of consideration, depending on the degree of reasonable reliance involved; (3) that the concept of fairness should be understood as applying to all taxpayers generally and not just to members of a group adversely affected by a retroactive change; and (4) that fiscal considerations in and by themselves should never be relied on in support of a retroactive change. ${ }^{.46}$

The upshot of both the more general philosophical accounts of the de-

that the general principles of the constitution (as for example the right to personal liberty, or the right of public meeting) are with us the result of judicial decisions determining the rights of private persons in particular cases brought before the Courts; whereas under many foreign constitutions the security (such as it is) given to the rights of individuals results, or appears to result, from the general principles of the constitution."

${ }^{42}$ For a brief but instructive elaboration on these five elements, see Lawrence B. Solum, "Legal Theory Lexicon: The Rule of Law" (July 5, 2009) available online at: http://lsolum.typepad.com/legaltheory/2009/07/legal-theory-lexicon-the-rule-oflaw.html.

${ }^{43}$ Among these general principles for Raz are that "all laws should be prospective, open and clear" and that "laws should be relatively stable." See Joseph Raz, "The Rule of Law and It's Virtue" (1977) 93 The Law Quarterly Review 195.

${ }^{44}$ See Lon Fuller, The Morality of Law, 2nd ed. (Yale University Press, 1969).

${ }^{45}$ See Geoffrey Loomer, "Taxing Out of Time: Parliamentary Supremacy and Retroactive Tax Legislation" [2006] British Tax Review 64.

${ }^{46}$ See Thomas E. McDonnell, "Retroactivity: Policy and Practice," in report of Proceedings of the Fifty-Eighth Tax Conference, 2006 Conference Report (Toronto: Canadian Tax Foundation, 2007), 2:1-33. 
mands of the rule of law and the writings that are more practical and focused on the taxation context is that retroactive legislation that violates the legitimate expectations of taxpayers is impermissible. This raises a number of questions, however, surrounding just what precisely constitutes the legitimate expectations of taxpayers when taxpayers are engaged in tax avoidance, and whether the described impermissibility is absolute or only cautionary. It is enough, however, for the purposes of this paper to emphasize that retroactive laws are generally inconsistent with the demands that the law be knowable ex ante and for that reason be capable of reliably guiding taxpayer behavior.

\subsection{Political Economy}

A dictum attributed to Jean-Baptiste Colbert states that, "the art of taxation consists in so plucking the goose as to obtain the largest amount of feathers with the least amount of hissing." 47 There are several mechanisms through which the political economy environment affects the timing and general timidity of government responses to tax avoidance. ${ }^{48}$ The most significant is likely the one rooted in the observation that the loss to the public purse from tax avoidance is felt diffusely and usually remotely in time, whereas the gain to the taxpayer from tax avoidance is immediate, direct, acute, and often personal. ${ }^{49}$ This raises a collective action problem that must be solved through administrative means. This, in turn, faces numerous obstacles. For example, whereas each taxpayer is ideally situated to know the information that affects his or her tax situation, it is considerably more difficult for the government to monitor the information that pertains to each taxpayer's liability. A rational taxpayer taking a selfish perspective would be willing to pay up to the amount of their tax liability in order to avoid having to pay that tax liability,

\footnotetext{
${ }^{47}$ This is an old French maxim, often attributed to Jean-Baptiste Colbert (1619-1683). The maxim is quoted in Jeffery L. Yablon, "Certain as Death-Quotations About Taxes" (January 9, 2006) 110 Tax Notes 103 at 123.

${ }^{48}$ For a book length treatment addressing a number of these issues, see Henry J. Aaron and Joel Slemord, eds., The Crisis in Tax Administration (Brookings Institution Press, 2004).

${ }^{49}$ In an influential contribution, political scientist Terry M. Moe wrote that, "American public bureaucracy is not designed to be effective. The bureaucracy arises out of politics, and its design reflects the interests, strategies, and compromises of those who exercise political power." See Terry M. Moe, "The Politics of Bureaucratic Structure" in John E. Chubb and Paul E. Peterson, eds., Can the Government Govern? (Brookings Insitution Press, 1989), 273-329 at 273.
} 
whereas governments are generally willing to expend far fewer resources on auditing and enforcing income tax laws. Thus, there are three important asymmetries that contribute to the phenomenon of tax avoidance: (1) an asymmetry in the concentration of stakes (diffuse for government versus concentrated for taxpayers); (2) an asymmetry in information (typically less for governments versus more for taxpayers); and (3) an asymmetry in the resources devoted by governments in enforcement and taxpayers in avoidance (less on enforcement by governments and more by taxpayers in avoidance). ${ }^{50}$

These three asymmetries play out in a number of ways. Consider that for any individual employee of the tax administration, it will naturally be the case that the taxpayers that they interact with are more keen to avoid additional tax liability than the employee of the tax administration will be keen to enforce the tax law to its full extent (though they may well be keen to do so, they will be less keen than they would if they personally were allowed to keep the in full whatever is recovered in tax, interest, and penalties collected from the taxpayer). While most tax administrators are apt to be honest and dutiful servants, the differing incentives facing the employees versus the taxpayers that they interact with can reasonably be expected to manifest themselves in suboptimal exertion on investigation and enforcement of the tax law. It is probably easiest to imagine this suboptimal enforcement in the context of a negotiated settlement to a dispute regarding the extent of tax, interest, and penalties owing with respect to an alleged underpayment of tax. In these circumstances, the prediction is that the settlement will, all else the same, tend to favour the taxpayer (relative to what the outcome would on average be in judicial proceedings). ${ }^{51}$

Moving from tax administration to tax legislation, Parliament is apt to be slower than taxpayers in the tax avoidance context. When creative tax planners devise a new unanticipated scheme that manages to avoid tax under plausible interpretations of current income tax law, it is reasonable to expect these innovations to spread relatively quickly within the tax planning community (most obviously often within the same law firm or accounting firm). In Canada, for Parliament to respond, the Canada Revenue Agency ("CRA") must first both learn of the innovation and identify it as a possible concern. The CRA then consults with the Department of Finance about the

\footnotetext{
${ }^{50}$ These features are inter-related but each is nevertheless of independent importance.

${ }^{51}$ Conversations with several prominent Canadian tax practitioners suggest that the argument from theory plays out, albeit to a limited extent, in practice.
} 
nature of its concerns. The Department of Finance will then study the issue to determine whether it shares the same concerns as the CRA and, if so, the Department will then formulate a draft legislative response that addresses the issue. Finally, the governing party of the day in Parliament will have to decide that it is in its best interests to pass whatever amendment has been developed by the Department of Finance. All of this, naturally, takes time.

\section{Price Discrimination}

Adopting a price discrimination account of why governments are relatively lax in combating tax avoidance generates a new and fresh account surrounding the advantages of delayed and predominantly prospective responses to tax avoidance. In order to explain the operation of the price discrimination mechanism in the context of income taxation, subpart 4.1 describes the three principal types of price discrimination identified by industrial organization economists. Subpart 4.2 explains the main modifications that must be made to the usual producer-consumer paradigm of most price discrimination models in order to apply their analyses to income taxation. With these modifications in place, subpart 4.3 discusses how each of the three types of price discrimination can be adapted to apply in the context of income taxation. Subpart 4.4 explains that while the implications of third-degree price discrimination are reasonably well understood in the optimal income tax literature, ${ }^{52}$ it is actually second-degree price discrimination that best accounts for the observed softness of governments with respect to tax avoidance.

\subsection{What is Price Discrimination?}

A leading economics text on industrial organization states that, "It is hard to come up with a satisfactory definition of price discrimination. Roughly, it can be said that the producer price-discriminates when two units of the same physical good are sold at different prices, either to the same consumer or to different consumers." ${ }^{53}$ Although one cannot reasonably doubt Tirole that it can be difficult to provide an entirely satisfactory definition of price

\footnotetext{
${ }^{52}$ See, for example, Gregory Mankiw and Matthew Weinzierl, "The Optimal Taxation of Height: A Case Study of Utilitarian Income Redistribution" (May 2009) NBER Working Paper No. 14976, available online at: http://www.nber.org/papers/w14976.pdf.

${ }^{53}$ Jean Tirole, The Theory of Industrial Organization (MIT Press, 2003) at 133.
} 
discrimination, not least because of the many caveats and assumptions necessary, economists following Pigou ${ }^{54}$ typically identify three degrees of price discrimination.

First-degree or "perfect" price discrimination occurs when a producer is able to identify precisely the willingness to pay for a good or service of each consumer and can prevent the resale of the good or the service in a secondary market. In these circumstances a profit-maximizing producer will choose to charge each consumer a price equal to each consumer's maximum willingness to pay. In doing so, the producer will supply the entire market in way that will ensure economic efficiency ${ }^{55}$ and extract all available consumer surplus from the purchasers of the good or service. To be operational perfect price discrimination requires that strong assumptions be made. More specifically, the producer of the good or supplier of the relevant service must have complete information about the willingness to pay of consumers and it must be possible to prevent arbitrage in the secondary market for the good or service. ${ }^{56}$ Perfect price discrimination is, for that reason, largely regarded as being of theoretical interest rather than an empirically realistic phenomenon. ${ }^{57}$

Second-degree price discrimination occurs when the producer has incomplete information about the preferences of particular consumers and cannot reliably target individuals or groups of consumers for particular pricing strategies. The producer will in general, however, have information about the mix of consumer preferences in the population. Unlike perfect price discrimination, where the producer knows precisely the willingness to pay of each consumer, in second-degree price discrimination the producer is aware only of the distribution of willingness to pay among consumers. In these circumstances the goal of the producer is to induce consumers with different willingness to pay to choose different price-quantity bundles from a menu of options offered by the producer. If a producer is successful in setting a menu of price-quantity bundles that cause consumers with different will-

\footnotetext{
${ }^{54}$ A.C. Pigou, The Economics of Welfare (London: Macmillan, 1920). See also Tirole, ibid., at 135 .

${ }^{55}$ It will be consistent with economic efficiency in the sense that theoretically every individual who values the product at a level at least equal to its joint cost of production and delivery will be supplied with the product.

${ }^{56}$ Otherwise low willingness to pay consumers would buy more than they would like to consume and then compete with the producer in making sales at higher prices to high willingness to pay consumers.

${ }^{57}$ See Tirole, supra note 52, at 135 .
} 
ingness to pay to choose different bundles, then the producer will secure a greater share of the consumer surplus than uniform pricing would facilitate. ${ }^{58}$ Naturally, inducing the separation of consumers into different consumption bundles requires incentive-compatibility between the bundles on offer and the willingness to pay of each consumer. ${ }^{59}$ An example of second-degree price discrimination would be a coupon that entitles the bearer of the coupon to a discount. It will systematically tend to be the case that more price sensitive consumers will make use of the coupon. ${ }^{60}$

Third-degree price discrimination relies on an exogenous attribute of consumers that can be observed by the producer that is correlated with the consumers' willingness to pay. Unlike second-degree price discrimination, where the distribution of willingness to pay among consumers is known, but nothing is known about the willingness to pay of any particular consumer, in thirddegree price discrimination the producer is able to observe certain attributes of consumers that are linked to higher or lower willingness to pay for the good or service. An example of third-degree price discrimination would be discounts that are made available only to seniors or students. ${ }^{61}$ If seniors or students have systematically lower willingness to pay for a particular good or service and yet are still willing to pay enough to cover the marginal cost to the producer of the good or service, it will be profitable for the producer to service the customers by allowing them to self-identify as members of the relatively low willingness to pay group.

\subsection{Producer-Consumers to Government-Taxpayers}

It is possible to translate these three types of market-based price discrimination to versions that correspond with the task facing governments in setting the various structural features of income tax law. More specifically, we can treat the government as the producer and price-setter of the good or ser-

\footnotetext{
${ }^{58}$ See Tirole, ibid., at 146.

${ }^{59}$ For a formal analysis of these ideas in the context of the insurance market, see Joseph Stiglitz, "Monopoly, Nonlinear Pricing, and Imperfect Information: The Insurance Market" (1977) 44 Review of Economic Studies 407.

${ }^{60} \mathrm{On}$ the use of coupons as tool to achieve second-degree price discrimination, see Naufel Vilcassim and Dick R. Wittink, "Supporting a Higher Shelf Price Through Coupon Distributions" (1987) 4(2) Journal of Consumer Marketing 29.

${ }^{61}$ The assumption is that private businesses would not have an incentive to engage in redistribution from some customers to others, but that they are willing to supply to pricesensitive consumers on terms that nevertheless exceed marginal cost.
} 
vice and characterize the taxpayers as the customers in the conventional account. To be sure, however, the translation is not direct. There are important differences between the typical producer-consumer interaction and the government-taxpayer interaction. For example, the government as tax collector does not typically provide goods or services in exchange for the taxes that are paid by taxpayers. ${ }^{62}$ Moreover, because the government in this account is not providing any good or service, there is no marginal cost function associated with producing a good or service linked directly to an interaction with any particular taxpayer. This suggests that there are two significant modifications that must be made to get the price discrimination account of income taxation off the ground - one on the government's side and one on the taxpayer's side.

\subsubsection{The Government as Producer}

It is not immediately obvious how to translate the free market, private forprofit producer version of price discrimination to the context of interest - tax avoidance. For the purposes of the price discrimination account the translation requires the government to take on the role of the producer. The central challenge is that, unlike a private producer that can be assumed to be seeking to maximize its profit, it is not at all obvious that the government's objective function corresponds to maximizing its tax revenues. Because of this, there must be an assumption made about how much revenue the government desires to raise through the income tax system. The simplest approach, which will be the one adopted here for the purposes of exposition, is to assume that the expenditure determination is independent and exogenously given. This assumption, while artificial, yields the reasonable result that the government's objective in structuring the income tax is to collect a specific amount of income tax in the "best" way possible. ${ }^{63}$ In light of the foregoing, assume

\footnotetext{
${ }^{62}$ Governments do typically provide many valuable benefits to taxpayers (infrastructure, health care, education, policing, national defence, etc.), but this is not an explicit quid pro quo arrangement in the sense that the entitlement to benefit from these public goods accrues to individuals qua citizens (or residents) and not to individuals qua taxpayers.

${ }^{63}$ More sophisticated versions of the government's targeted revenues are of course possible. For example, the government might seek to raise taxes to support additional government expenditure until the marginal social rate of return (i.e., the welfare gains associated with the last dollar of government expenditure) is precisely offset by the welfare losses associated with the last dollar collected through the tax system. While this yields a socially optimal link between the revenue-raising tax system and the expenditure side, it does
} 
that the government's goal is to raise a certain set amount of tax revenue through the income tax system.

\subsubsection{The Taxpayer as Consumer}

On the taxpayer's side, there is also a significant modification that must be made to the conventional price discrimination account. Here the issue is that taxpayer preferences do not yield a demand function of the kind typically associated with price discrimination models. In most models of price discrimination, consumers are assumed to exhibit declining willingness to pay for each additional unit of the good or service provided by the producer. Because there is no explicit quid pro quo in income taxation, it is not possible to derive directly this kind of demand function on the taxpayer side. It is, however, possible to substitute a measure of taxpayer responsiveness for the more conventional demand function.

By responsiveness I mean to refer to the capacity of taxpayers, either directly or, more commonly, by proxy through a tax adviser, to respond in various ways to mitigate their effective tax obligations. For some taxpayers, especially those with operations that span many jurisdictions, the most natural way to respond will be to relocate their income-earning operations to another jurisdiction, directly or indirectly. Another way that taxpayers might respond to greater tax obligations is by working less. Some taxpayers will be moved by higher rates to seek out other tax sheltering opportunities. To the extent that taxpayers are motivated to actually reduce their exposure to income tax through various behavioral channels, including shifting income to other jurisdictions, engaging in various tax avoidance transactions and, perhaps most worryingly from an efficiency perspective, simply deciding to be less productive by substituting leisure for labor, ${ }^{64}$ they are being responsive in the sense of the word intended. For many taxpayers, there is little scope on the margin for rearranging their income-earning activities so as to mitigate an enhanced tax liability. Put simply, the solution offered to the translation from consumer to taxpayer is to replace the usual measure of consumer preferences, the demand function, with a function representing the responsiveness of taxpayers to higher prima facie income tax burdens.

nothing to alter the stylized account of government as price discriminator offered here.

${ }^{64}$ That this might be concerning is not uncontroversial. See, for example, Bertrand Russell, In Praise of Idleness and Other Essays (Allen \& Unwin, 1935). 
Stylistically and for the purposes of exposition, one can imagine taxpayers falling into one of three groups: (1) highly sophisticated taxpayers; (2) taxpayers of ordinary sophistication; and (3) less sophisticated taxpayers. Although these categories are apt to be somewhat inexact it is possible to differentiate among them as follows. The most sophisticated group of taxpayers understands that the income tax system is complicated and that this complexity comes with both opportunities and pitfalls. The hallmark of the most sophisticated group of taxpayers is an ability to proactively manage and plan their income-earning activities in order to minimize their tax liabilities. Sophisticated taxpayers will typically retain elite tax professionals who assist them in developing plans to minimize their tax liabilities. The vast majority of taxpayers, of course, will not be highly sophisticated and instead will out of necessity not be proactive in managing their tax liabilities. Instead, these taxpayers will tend to be focused on compliance. The hallmark of individuals in this category is that they will be reactive rather than proactive. They will not generally be forward-looking in managing and planning their income-earning activities, and instead focus on complying ex post with their tax obligations each fiscal year. Most small and medium sized businesses and middle to high income taxpayers will on this account be properly regarded as being of ordinary sophistication. When taxpayers of ordinary sophistication hire tax advisors or consult resources, they most often turn to non-elite tax professionals, such as tax preparation services, small accounting firms, or software programs. ${ }^{65}$ Another group of taxpayers is less sophisticated still. For these individuals the demands of the income tax system are intimidating and sometimes overwhelming and daunting. These taxpayers are generally of more limited means, less well educated, and often have more significant challenges (or at least challenges that loom larger) than tax compliance. It should be clear from this account that taxpayers of ordinary and low sophistication are unlikely to be responsive to (or, realistically, to be much affected by) legislative changes addressing tax avoidance. Instead, taxpayer responsiveness to anti-avoidance measures is largely a phenomenon involving highly sophisticated taxpayers.

\footnotetext{
${ }^{65}$ On the implications of the growth of software-aided tax compliance, see Austan Goolsbee, "The TurboTax Revolution? Evaluating the Ability of Technology to Solve the Tax Complexity Dilemma" in Henry J. Aaron and Joel Slemrod, eds., The Crisis in Tax Administration (Brookings Institution Press, 2004), 124-137.
} 


\subsection{Price Discrimination in Income Taxation}

In order to analyze the application of ideas taken from the industrial organization literature relating to price discrimination in the income taxation context, it will be helpful first to set out how each of the three degrees of price discrimination can be translated into the income tax environment.

\subsubsection{First-Degree Price Discrimination in Income Taxation}

On the assumption that conditions make it possible for governments to perfectly price discriminate, how would a perfectly price discriminating government behave in the income taxation context? A government that was able to directly observe the responsiveness to income tax of every individual taxpayer would be able to assess and collect income taxes from each individual in a personally tailor-made amount. In theory, the idea would be to extract from each individual taxpayer an amount of tax that, on the margin, equates the welfare losses for each taxpayer, subject of course to the assumed revenue demands of the government. ${ }^{66}$

\subsubsection{Second-Degree Price Discrimination in Income Taxation}

To the extent that governments can anticipate a certain distribution of responsiveness to income taxation in a given group, but are unable to identify ex ante who among that group will be more or less responsive, there may be scope for second-degree price discrimination. As mentioned above, for second-degree price discrimination to be effective there must be a common set of options that are available to all taxpayers of low and high responsiveness such that taxpayers of different responsiveness respond predictably differently.

One way that a government might achieve this outcome is by setting out a relatively high "advertised" tax rate that applies on a tax base that is common

\footnotetext{
${ }^{66}$ If one assumes that the government's fiscal policy optimally integrates revenues and expenditures, then the marginal welfare loss of the income tax to each individual taxpayer would be equal to the marginal social return to government expenditures. Where there is not optimal integration between the revenues and expenditures, first-degree price discrimination would result in the government satisfying its revenue raising demands by imposing tax on each taxpayer such that (1) each taxpayer contributes to the point of equal marginal welfare loss; and (2) the government satisfies its exogenously determined revenue requirements.
} 
to all taxpayers. Because all taxpayers will be governed by the same set of rules (i.e., the provisions of the Income Tax Act or the Internal Revenue Code), one can regard this as an invitation to taxpayers to choose among the tax treatments permitted by the legislation. ${ }^{67}$ More highly responsive taxpayers will be able to proactively manage their income tax burden through innovative tax avoidance measures (shifting income to other jurisdictions, using sophisticated tax shelters, etc.) more easily than will low responsiveness taxpayers. In general the result will be that high responsiveness taxpayers will be able to help themselves to effective tax rates that are much lower than the advertised tax rate that will apply to low responsiveness taxpayers.

There are likely to be social welfare gains from this kind of a system since this form of price discrimination will tend to promote a better correspondence between the marginal welfare loss to each taxpayer from taxation and the marginal social gain in government expenditures than would be associated with an income tax system that did not permit this kind of screening according to taxpayer responsiveness. To the extent that it is realistic to believe that there will be a group of sophisticated taxpayers in favor of whom it will be difficult for the government to discriminate explicitly, then there will be a case for half-hearted anti-avoidance.

\subsubsection{Third-Degree Price Discrimination in Income Taxation}

If governments are capable of identifying certain attributes of taxpayers that are positively or negatively correlated with taxpayer responsiveness to taxation, then there is scope for third-degree price discrimination. ${ }^{68}$ Determining how to exploit imperfect information about taxpayers to tax them optimally using measures akin to third-degree price discrimination has been the preoccupation of the optimal taxation literature pioneered by William S. Vickrey ${ }^{69}$

\footnotetext{
${ }^{67}$ This conventional form of tax avoidance is referred to as "transactional substitution" by Tim Edgar; see Edgar, supra note 10 .

${ }^{68}$ In the economics literature these observable attributes are, following Akerlof, sometimes referred to as "tags." See George Akerlof, "The Economics of 'Tagging' as Applied to the Optimal Income Tax, Welfare Programs, and Manpower Planning" (1978) 68(1) American Economic Review 8.

${ }^{69}$ See William S. Vickrey, "Measuring Marginal Utility by Reactions to Risk" (1945) 13 Econometrica 319.
} 
and James Mirrlees, ${ }^{70}$ and extended more recently by others. ${ }^{71}$

An interesting application of this idea of third-degree price discrimination in income taxation was recently analyzed by the economists Gregory Mankiw and Matthew Weinzierl. Mankiw and Weinzierl observe that taller taxpayers tend, all else the same, to have higher ability to pay income tax (and therefore, according to their assumptions, lower responsiveness to income taxation) than shorter taxpayers because taller taxpayers tend to have higher incomes. Using this observation, they ask, "Should the income tax include a credit for short taxpayers and a surcharge for tall ones?"72 According to Mankiw and Weinzierl, "a person's height is strongly correlated with his or her income." ${ }^{\prime 3}$ The evidence that the authors review suggests that each additional inch of height of an individual is associated with an additional $1.8 \%^{74}$ or $2.0 \%^{75}$ increase in wages, even after controlling for gender, weight, and age. ${ }^{76}$ The upshot of this for Mankiw and Weinzierl is that optimal tax theory - at least insofar as it maps on to third-degree price discrimination - suggests that "a tall person of a given income should pay more in taxes than a short person of the same income."77

${ }^{70}$ James A. Mirrlees, "An Exploration in the Theory of Optimal Income Taxation" (1971) 38 Review of Economic Studies 175; and James A. Mirrlees, "The Theory of Optimal Taxation" in K.J. Arrow and M.D. Intrilligator, eds., Handbook of Mathematical Economics (1986) 1198-1249.

${ }^{71}$ For recent contributions extending the analysis of Vickrey and Mirrless see Emmanuel Saez, "Using Elasticities to Derive Optimal Income Tax Rates" (2001) 68 Review of Economic Studies 205; Narayana Kocherlakota, "Zero Expected Wealth Taxes: A Mirrlees Approach to Dynamic Optimal Taxation" (2005) 73(5) Econometrica 1587; and Stefania Albanesi and Christopher Sleet, "Dynamic Optimal Taxation with Private Information" (2006) 73 Review of Economic Studies 1.

${ }^{72}$ See Mankiw and Weinzierl, supra note 51 , at 1.

${ }^{73}$ Ibid., at 2.

${ }^{74}$ Nicola Persico, Andrew Postlewaite, and Dan Silverman, "The Effect of Adolescent Experience on Labor Market Outcomes: The Case of Height" (2004) 112(5) Journal of Political Economy 1019.

${ }^{75}$ Anne Case and Christina Paxson, "Stature and Status: Height, Ability, and Labor Market Outcomes" 116(3) Journal of Political Economy 499.

${ }^{76}$ Mankiw and Weinzierl, supra note 42 , at 2.

${ }^{77}$ Ibid. At 13, the authors acknowledge the intuitive lack of appeal of the claim that height might theoretically be regarded as a useful means of discriminating among taxpayers and so they emphasize that, perhaps, "the Utilitarian model needs to be supplanted with another normative framework." They conclude, also on 13, with the observation that,

Our results, therefore, leave readers with a menu of conclusions. You must either advocate a tax on height, or you must reject, or at least signifi- 


\subsection{The Integrated Price Discrimination Account}

With the benefit of the foregoing discussion it is possible to construct an illuminating new account of the tax policy contours underlying the structural features of most income tax systems and, moreover, explain the relatively lax response to tax avoidance witnessed in developed countries.

Before putting these pieces together, however, it is worthwhile to acknowledge that a conceptual challenge on any of these price discrimination accounts is how appropriately to approach the taxation of corporations and other non-fiscally transparent entities. ${ }^{78}$ Individual taxpayers ultimately bear the incidence of corporate income taxes, so it seems that the proper approach would be to look through corporate and other non-fiscally transparent entities to assess the individual responsiveness of each shareholder. ${ }^{79}$ This would seem to be necessary because it is quite possible that the responsiveness of individual shareholders will vary dramatically. ${ }^{80}$ The price discrimination account that I develop here does not address this issue directly. However, one possibility is to regard corporations as likely to be more responsive to taxes than its shareholders individually are likely to be, not least because corporations are more likely to hire elite tax professionals to assist in tax mitigation. ${ }^{81}$

How can the three price discrimination accounts be integrated into a single story? The perfect price discrimination and third-degree price discrimination stories, as recounted above, bear striking resemblance to optimal tax theory. With respect to perfect price discrimination, optimal tax theory

cantly amend, the conventional Utilitarian approach to optimal taxation.

The choice is yours, but the choice cannot be avoided.

${ }^{78}$ This is not a challenge restricted to the price discrimination account, however. It is a well-known issue in tax policy more generally. For treatments of this issue see Richard M. Bird, "Why Tax Corporations?" (1996) Technical Committee on Business Taxation Working Paper 96-2 (Ottawa: Department of Finance); and Kim Brooks, "Learning to Live with an Imperfect Tax: A Defence of the Corporate Tax" (2003) 36 British Columbia Law Review 621.

${ }^{79}$ This is the approach taken to partnerships in the Income Tax Act, R.S.C. 1985, c. 1 (5th Supp.), as amended.

${ }^{80} \mathrm{It}$ is grossly unrealistic to think, for example, that a wealthy majority shareholder will be equally responsive as a widowed pensioner shareholder in the same firm.

${ }^{81} \mathrm{~A}$ reason to suspect that this is true is that corporate boards may be persuaded that their obligations to shareholders and other non-government stakeholders demand that they engage in tax mitigation. 
would acknowledge that basing tax liability expressly on the elasticity of a taxpayer's responsiveness would be impractical (as was concluded above). With respect to third-degree price discrimination, optimal tax theory would account for a number of features of current tax systems as being proxies for sensitivity to taxation. Tax advantages targeted at certain groups could be accounted for by invoking an increased sensitivity to tax liability linked to a certain trait, not unlike discounts offered to students or seniors. In the Canadian income tax system, employees are permitted far fewer deductions than are similarly situated independent contractors. ${ }^{82}$ Similarly, in Canada employees face mandatory income tax withholding at source and information reporting by employers, whereas independent contractors do not face a regime of mandatory information reporting. ${ }^{83}$

The way to integrate the possibilities flowing from third-degree price discrimination is to realize that once the opportunities for third-degree price discrimination are exhausted, what remains is the possibility for second-degree price discrimination. More specifically, if there is no longer any scope for discriminating among taxpayers based on observable traits, then the income tax can leave open self-selection among taxpayers into various types of tax avoidance. The tax avoidance contemplated by a second-degree price discriminating government at this point could be explicitly approved (i.e., tax expenditures) or it could merely be condoned temporarily and tacitly. In either event, the idea would be to allow taxpayers to further refine their tax liabilities according to their own responsiveness to taxation.

The policy implications of this integrated price discrimination account are addressed next.

\section{$5 \quad$ Policy Implications}

There are a number of policy implications of the integrated price discrimination account to be explored. Several significant implications are discussed below. $^{84}$

\footnotetext{
${ }^{82}$ Employees may only deduct amounts from their employment income that are specifically provided for in the Income Tax Act; see subsection 8(2).

${ }^{83}$ Independent contractors do, however, have to make installment payments of tax, which functions similarly in practice (but not identically) to withholding at source for employees.

${ }^{84}$ [Note to readers of this draft: this section is still preliminary. I would appreciate feedback particularly on the policy implications of the foregoing. I expect that there are other implications that I have not yet recognized.]
} 


\subsection{Tax Rates and Anti-Avoidance Strictness}

There is stark choice confronting tax policymakers emerging from the foregoing account. The choice is between (1) a high rate income tax system combined with a relatively lax approach to tax avoidance; or (2) a lower rate income tax system with a relatively strict approach to tax avoidance. Because most tax systems have decided not to rely extensively on retroactive specific anti-avoidance rules or multiple alternative tax bases, I suggest that it is clear that most governments can be characterized as having embraced the first choice.

If a government's aim is to raise a certain targeted amount of revenue, in the long-run there is not likely to be a third option to be had in which a tax system has a low tax rate and a relatively lax approach to tax avoidance that satisfies a government's revenue-raising demands. In the short-run, it is possible that such an option might be available, depending on the tax systems adopted by other jurisdictions. For example, in the transfer pricing context it is likely that the country with the lowest effective tax rate on business income will generate more revenue by having lower rates than it would generate if its rates were not the lowest because of income-shifting into the jurisdiction from higher tax rate jurisdictions. In the long-run, however, these will largely be transitory gains, even if they do happen to be repeated transitory gains in a race to the bottom. Indeed, if a jurisdiction becomes accustomed to this income-shifting tax revenue, it should not be surprised if it becomes a participant in a race to the bottom that will - if the strategy is not abandoned - lead to it becoming insolvent or a tax haven. Thus, I argue that the only real choice is between being a high rate income tax jurisdiction with relatively law anti-avoidance or a lower rate income tax jurisdiction with strict anti-avoidance. There is no long-run alternative.

It is necessary to maintaining the first option (i.e., having a high rate income tax system with lax anti-avoidance) to engage in enough anti-avoidance measures in order to maintain discrimination between the highly responsive taxpayers and less responsive taxpayers. A serious concern must always be that tax avoidance strategies might percolate down from innovative and nimble highly responsive taxpayers to less innovative and less responsive taxpayers. Thus, even a government that adopts a high rate income tax system with half-hearted anti-avoidance must be on guard against being too lax on tax avoidance. It is this last point that bridges the explanatory gap left by the rule of law and the political economy accounts. It is only with constant half- 
hearted anti-avoidance that a government second-degree price discriminating in this way can maintain its revenues. In these circumstances, it is quite clear why governments might simultaneously complain about tax avoidance and also why they would also not pursue all measures legally available to combat it.

\subsection{Discriminating Among Types of Income}

One of the curious features of the Canadian income tax is the relatively disadvantaged treatment accorded to income from employment versus business income. ${ }^{85}$ One way to understand this disparate treatment is to realize that employees (and labor more generally) are systematically apt to be less responsive to higher tax burdens than businesses, not least because businesses typically are more able to respond to higher tax burdens by shifting incomeearning activities to other jurisdictions (either de jure or de facto) than are employees. In addition, the discipline imposed by product markets is likely to force the hand of businesses that operate in highly competitive industries to respond more aggressively, all else the same, than employees.

The fact that price discrimination can lead to treating different types of income in different ways is made abundantly clear in the Nordic dual income tax systems. In dual income tax systems, the discrimination between different types of income is categorical and explicit. Labor income is subject to progressive rates of taxation, while income from capital is subject to lower and flat rates of taxation. ${ }^{86}$ The key structural defining feature of dual income tax systems is driven by the recognition that income from capital can be much more mobile and therefore exhibit much higher responsiveness to taxation than income from labour, which tends to be significantly less responsive. ${ }^{87}$

\footnotetext{
${ }^{85}$ This disadvantageous treatment is the reason for the "personal services business" antiavoidance rules in Canada's Income Tax Act; see paragraph 18(1)(p) and the definition of "personal services business" in subsection 125(7).

${ }^{86}$ For a discussion of dual income tax systems, see Peter Birch Sørensen, "Dual Income Tax: How and Why?" (2005) 61(4) FinanzArchiv: Public Finance Analysis 559.

${ }^{87}$ Ibid.
} 


\subsection{Justification of Tax Expenditures}

The tax expenditure concept considers any departure from an idealized income tax base as representing a substitue for direct government spending. ${ }^{88}$ On this basis, Stanley Surrey was critical of tax expenditures and argued that indirect government spending through the Internal Revenue Code ought to be subject to the same scrutiny as direct government spending. Surrey's appeals for more transparency with respect to indirect government spending occasioned through the US federal income tax subsequently gave rise to tax expenditure reports in the US and Canada, among other countries, that identify and try to quantify tax expenditures. ${ }^{89}$

The dynamic of second-degree price discrimination requires that more responsive taxpayers be able to self-select into more attractive tax treatment in a way that is difficult to mimic by less responsive taxpayers. For the dynamic to operate, there can be either merely condoned tax avoidance of the traditional sort or there can be explicitly endorsed opportunities for tax avoidance offered through various tax expenditures. Thus, one way of understanding the proliferation of tax expenditures in many jurisdictions is as an unambiguously legal channel for responsive taxpayers to secure more attractive tax treatment. The requirement of having to maintain the distinction between highly responsive and less responsive taxpayers also accounts for two other phenomena: (1) the 1986 tax reform in the U.S. that eliminated many tax expenditures; ${ }^{90}$ and (2) alternative minimum taxes. ${ }^{91}$ Each of these reforms can be regarded as a way of trying to restore the integrity of the self-selection mechanism used by more responsive taxpayers.

Indeed, in order to ensure that the second-degree price discrimination mechanism can continue to ensure that a separating equilibrium is main-

\footnotetext{
${ }^{88}$ For a seminal academic contribution on the concept of tax expenditures, see Stanley S. Surrey, Pathways to Tax Reform: The Concept of Tax Expenditures (Harvard University Press, 1973).

${ }^{89}$ For a recent extended academic treatment of tax expenditures, see Lisa Philipps, Neil Brooks, and Jinyan Li, Tax Expenditures: State of the Art (Canadian Tax Foundation, 2011).

${ }^{90}$ See Joint Committee on Taxation, "General Explanation of the Tax Reform Act of 1986" (U.S. Government Printing Office, 1987), available online at: http://www.jct.gov/jcs-10-87.pdf.

${ }^{91}$ See Congressional Budget Office, "The Alternative Minimum Tax" (April 15, 2004) Revenue and Tax Policy Brief No. 4, available online at: http://www.cbo.gov/ftpdocs/53xx/doc5386/04-15-AMT.pdf. See also the references in notes $32-34$, supra.
} 
tained (i.e., that less responsive taxpayers pay the high "advertised" tax rates, and only more responsive taxpayers pay lower-than-advertised tax rates) a prediction of the price discrimination account of income taxation is that there must periodically be a "tightening" or "resetting" of tax advantages that have crept into the income tax.

\section{Conclusion}

The puzzle that prompted this paper is how is it that governments simultaneously complain about tax avoidance and also stand by and let it happen without using the best available weapons to counter it. The rule of law provides some clues about the tepid response of governments to tax avoidance, as does the brute fact that not all legally available measures will be particularly attractive or feasible for governments to pursue. But the rule of law and political economy do not provide a satisfactory resolution to the puzzle. They can explain governments not taking all available actions against tax avoidance, but provide no account of the circumstances in which we should expect governments to intervene aggressively to combat tax avoidance.

This paper has provided an account that explains both reluctant antiavoidance in most circumstances and aggressive anti-avoidance in other circumstances. More specifically, under plausible assumptions the income tax system acts as a second-degree price discrimination mechanism through which the most responsive taxpayers (among the group of most sophisticated taxpayers) self-selects into lower effective income tax rates and less responsive taxpayers (also among the group of the most sophisticated taxpayers) are left facing relatively higher income tax liability. The operation of the self-selection mechanism can be either through explicit tax expenditures or through traditional tax avoidance (i.e., tax planning). In either case to maintain the usefulness of the self-selection mechanism a price discriminating government must remain cognizant of the possibility of the screening function breaking down through the mimicking of tax avoidance strategies by less responsive taxpayers or the excessive use of tax expenditure provisions on the part of less responsive taxpayers. When this happens, the government

will predictably step in to change the law prospectively. Where learning by less responsive taxpayers is too fast (such that low responsiveness taxpayers are no longer paying tax at the relatively high advertised rates) or the government responds too slowly to new developments (again, such that 
low responsiveness taxpayers are no longer paying tax at the relatively high advertised rates), the result can be what is perceived as a result that runs counter to the predictions of the rule of law and to the political economy accounts, but can be accommodated by the integrated price discrimination account.

It has been said that "an economy breathes through its tax loopholes." Previously it has not been clear precisely how and why this metaphor should be anything more than an anodyne for the consciences of aggressive tax avoiders (and possibly tax evaders). Now tax avoiders can comfort themselves on the basis that the argument developed here supports tax avoidance. On the other hand, the argument here also supports the conclusion that tax avoiders will inevitably have to relentlessly innovate in order to keep avoiding, with governments continuing to counter-innovate, perhaps only a step-anda-half or two behind them.

\footnotetext{
${ }^{92}$ This is quote is attributed to Barry Bracewell-Milnes in Frank A. Cowell, Cheating the Government: The Economics of Evasion (MIT Press, 1990) at 195.
} 